\title{
Analysis of the Policy of the Republic of Uzbekistan Regarding International Non-governmental Organization
}

\author{
Ernazarov Dilmurod Zukhriddinovich \\ Department of Social Sciences, Faculty of Accounting and Auditing, Tashkent State University of Economics (TSEU), City Tashkent, \\ Uzbekistan
}

\author{
Email address: \\ dilm79@inbox.ru
}

\section{To cite this article:}

Ernazarov Dilmurod Zukhriddinovich. Analysis of the Policy of the Republic of Uzbekistan Regarding International Non-governmental Organization. Journal of Political Science and International Relations. Vol. 3, No. 1, 2020, pp. 9-15. doi: 10.11648/j.jpsir.20200301.12

Received: February 2, 2020; Accepted: February 20, 2020; Published: March 6, 2020

\begin{abstract}
This article analyzes the activities of international non-governmental organizations in Uzbekistan. Particular attention is paid to their relationship with state bodies, as well as their influence on the domestic policy of the country and society. The issue of the negative attitude of the government of Uzbekistan against international non-governmental organizations in 2004-2010 was studied. Also, the reasons for the positive changes in the attitude of the state towards international non-governmental organizations since 2016 have been studied. Today, the changing status of international nongovernmental organizations in pan-European and global institutions gives reason to believe that in the coming years they will play a dynamic role in various fields related to the reform and development of the countries of Central Asia and other CIS countries. INGOs in domestic politics, they act as an additional mechanism of public relations and play an active role in the formation of civil society, and in foreign policy as an instrument of public diplomacy and "soft power".
\end{abstract}

Keywords: States, Law, INGO, Proselytism, Human Rights, Civil Society, Democracy, Political Modernization and Tolerance

\section{Introduction}

International non-governmental organizations today play an important role in the development of the entire sphere in our country, they actively participate in the implementation of programs for the socio-economic development of this sphere, and render all possible assistance to state bodies in solving humanitarian problems.

The first international non-governmental organizations (INGOs) appeared in the 19th century. The strongest wave of their growth occurred in the econd half of the 20th century. Statistics clearly show this. In 1850 there were only 5 organizations, by 1914 There were already 330 of them, in 1939 - 730, in 1970 - 23000 , in 2000 - there were more than 45674 , by the end of the first decade of the XXI century the number approached 50000 . In 2014 alone, 142 organizations submitted to the economic and the United Nations Social Council (ECOSOC) application for consultative status (INGO), 36 of which were satisfied Vorenus [1].

However, now mankind has entered the stage of such a development of international relations, when states consciously lose the monopoly of the only subjects of such relations [2]. Other actors, including international nongovernmental organizations, become their active participants [3].

To date, the Ministry of Justice of Uzbekistan has registered about 30 representative offices and branches of various foreign and international organizations, whose central offices are in Germany, France, the USA, Russia, South Korea, Slovenia, the Netherlands and other countries.

They are making every effort to develop mutually beneficial cooperation in the field of healthcare and improve the sanitary and epidemiological situation, supply of free medicines and medical equipment, the economy, culture and art, social protection and labor protection, education, as well as in the training of highly qualified personnel for various industries and the exchange of specialists, scientists, graduate students and students. These organizations also carry out coordinated actions to protect the environment, improve the ecological situation, and prepare the population and interested state bodies in liquidating the consequences of natural disasters and catastrophes. Along with this, a constant 
exchange of experience and specialists has been established, as well as joint projects are being implemented in such areas as education, culture, sports, tourism, environmental protection, improving the environmental situation and other forms of humanitarian cooperation that contribute to better satisfying the spiritual and social needs of the population.

At the beginning of the XXIst century, INGO began to be spoken of as an effective political and social force. "Nongovernmental organizations play a key role in the formation and implementation of democratic structures. INGO have become quite independent participants in international relations [4].

The activities of international non-governmental organizations were primarily aimed at legal education of citizens, legal protection, free legal advice, legal education. It was a question of the legal charity of socially active people, whose life credo was selfless activity in the name of the humanity of social relations, the priorities of the interests of the individual. [5]

Undoubtedly, it is encouraging that individual foreign nongovernmental organizations pay great attention to the development of the healthcare sector in Uzbekistan. Together with interested state bodies, they resolve issues in the most problematic aspects of this area.

To date, affiliates of the non-governmental organizations Project Nora (Project Hope, USA), Save the Children (South Korea), Doctors Without Borders international charity (Netherlands) and the representative office of Medical Teams International (USA)) active work is being done in such areas as reproductive health, as well as the fight against AIDS, tuberculosis, malaria and many others.

For example, a branch of the non-governmental organization "Project Nore" ("Project Hope"), together with the Ministry of Health of the Republic of Uzbekistan, is implementing the project "High-quality healthcare: anti-TB component". The aim of this project is to improve the medical services for the prevention and treatment of tuberculosis provided to the population of Uzbekistan.

Also, a branch of the international charity organization Doctors Without Borders, together with the ministries of health of the Republic of Uzbekistan and Karakalpakstan, are implementing such projects as "Comprehensive treatment of tuberculosis for all in the Republic of Karakalpakstan" and others. These projects contribute to improving the diagnosis and treatment of tuberculosis, and as a result, improving the quality of services provided at all levels of the laboratory network and awareness of the population on the prevention of tuberculosis.

In essence, NGOs are the desire of people to meet certain social needs in discussing professional issues, the opportunity to realize their own aspirations in the religious and charitable sphere, and the desire to solve social problems of society. The emergence and development of non-governmental organizations reflects a certain stage in the development of civil society. The desire of NGOs to develop international contacts clearly demonstrates the commonality of the problems that these essentially social associations are trying to solve. [6]

And many of the theoretical propositions associated with INGO were perfectly suited to these aspirations. For INGO, these provisions are as follows:

The emergence and necessity of solving global problems, such as the protection of human rights and the environment;

Strengthening democratic processes in the field of domestic and international relations,

"Institutionalized expression" of which are nongovernmental organizations;

Transformations in the sphere of national interests of states:

Movement from state interests (sovereignty) to universal values;

The increasing desire of individuals to increase control over the decision-making process in matters that affect their vital interests;

Expanding the capabilities of cross-border relations and public activities in various countries, the capabilities of the technological process. [7]

During this period, the CIS states faced the task of legal regulation of the activities of local NGOs and international non-governmental organizations. They began to develop new laws that govern their activities within the country. In particular, during the period of the rise of public consciousness in different directions, including religious. An example of such legislation is:

The Law of the Republic of Uzbekistan "On NonGovernmental Non-Profit Organizations" dated April 14, 1999 No. 763-I;

The Law of the Kyrgyz Republic "On Non-Profit Organizations" of October 15, 1999, No. 111;

Federal Law of the Russian Federation "On Non-Profit Organizations" of July 19, 2007.

Law of Turkmenistan "On Public Associations" dated October 21, 2003 No. 197-II;

The Law of Tajikistan "On Public Associations" dated July 19, 2005 No. 36-3;

The Law of the Republic of Armenia "On Public Organizations" dated November 1, 1996, No. 3P-82;

The Law of the Republic of Armenia "On Socio-Political Organizations" of February 26, 1991, No. C-0266-1;

Law of the Republic of Moldova "On Public Associations" of 05.17.1996, No. 837;

The Federal Law of the Russian Federation "On Public Associations" dated February 2, 2006. [8]

Analysis of the literature. In the course of studying this issue, several monographs and scientific articles of Russian and foreign researchers were studied. For example, in the monographic work "International Organizations: Some Questions of the Theory" Academician G. Morozov first presented an analysis of the legal nature of international nongovernmental organizations, their concepts, internal structure, membership order, forms of financing, consultative relationships with intergovernmental organizations, their influence on state policy, which laid the foundation for 
further study of their activities. The second monograph by I. I. Kovalenko "International non-governmental organizations in modern international relations", which presents a historical analysis of the development of international nongovernmental organizations. A. I. Kamynin's $\mathrm{PhD}$ thesis, "International Non-Governmental Organizations in Contemporary International Relations," analyzes the activities of international non-governmental organizations from a political point of view.

As well as scientific articles by foreign researchers like AROL BRUNT and WILLY McCOURT, IDPM, University of Manchester, Manchester, UK, World Bank, Washington, DC, USA. University of Manchester, Manchester, UK. «Do international non-governmental organizationswalk the talk? Reconciling the 'two participations' in international development». Journal of International Development. J. Int. Dev. 24, 585-601 (2012) Published online in Wiley Online Library. (wileyonlinelibrary.com) DOI: 10.1002/jid.2851.

John Boli George M. Thomas, Emory University Arizona State University. World culture in the world polity: a century of international non-governmental organization. Source: American Sociological Review, Vol. 62, No. 2 (Apr., 1997), pp. 171-190.

\section{Research Methodology}

In the process of work, methods of analysis and synthesis, observation, comparative, historical, legal, functional, etc. were used. When writing the article, documentary material was used, based on and taking into account the generalized conclusions presented in the fundamental works of domestic and foreign expert scientists.

\section{Analysis and Results}

\subsection{Cold War Period}

In 2006, the Ministry of Justice of Uzbekistan registered a total of 73 representative offices and branches of international and foreign organizations. During the registration process, a number of non-governmental organizations received official warnings regarding violations of the laws of Uzbekistan in their activities. At this point, an official warning was issued to the missions of the National Democratic Institute of International Relations of the United States and the International Republican Institute (USA).

Separate violations were noted in the activities of the representative office of Freedom House organizations. This representation distributed printed literature in the form of cassettes, which biased and subjectively representing the social, political and socio-economic situation in Uzbekistan.

The Ministry of Justice, taking into account the short period of their activity in Uzbekistan, warned their leaders that in case of further violation of the law, the decision on registration will be reconsidered.

Due to intentional violations of the current legislation, the Ministry of Justice refused to register the representative office of the Institute of the Assistance Fund Society (Soros Foundation).

A deep analysis of the activities of international organizations showed that they systematically violated the national legislation of the Republic of Uzbekistan. Because of this, in order to ensure national security, the government began to close many other international organizations.

For example, on September 6, 2006, the Tashkent City Civil Court ruled to close the representative office of the nongovernmental organization Partnership in Academics and Development (PAD). The idea of the liquidation of this NGO was submitted to the court by the Ministry of Justice of Uzbekistan in late August.

According to the official version, the mission's employees were engaged in missionary work and proselytism on the territory of the republic, pushing the Uzbek people to change the traditional religion to Protestant Christianity, which is prohibited by the legislation of the country. In addition, the representative office was accused of creating structural units, using unregistered symbols, and providing access to the Internet without obtaining a license (visitors to the PAD office could use computers and access the Internet for free).

As expected, during the trial, all these allegations were supported by the testimonies of witnesses, mainly students of metropolitan universities. As one of them said, during his meeting with PAD foreigners, "attempts were made to spread the Bible and propagate the superiority of the Christian religion over Islam."

It was revealed that in private apartments as part of a group of eight, ten young men, religious rites and chants were held. According to him, at least once the illegal rite of baptism was carried out in the waters of the "Tashkent Sea" located near the capital, with the direct participation of foreigners.

In turn, the head of the representative office of Partnership in Academics and Development in Uzbekistan Albert Schenkel appealed to the court with a request to terminate the lawsuit in connection with the decision of the parent organization to close its representative office in Uzbekistan. However, in connection with the protest of the Ministry of Justice, this application was rejected. As a result, the court announced the decision to liquidate the Partnership in Academics and Development, which entered into force within 20 days from the date of its receipt by PAD representatives.

The PAD website says the organization provided small loans to farmers, trained journalists, sponsored business education and mental health counseling, and provided various services to students.

A ministry statement said that the PAD violated its charter by conducting missionary activities, mainly among university students. One student claimed that copies of the Bible were distributed at a meeting with foreign PAD staff at the Hamkorlik Center at the Uzbek State University of World Languages in Tashkent, and the "superiority of the Christian religion over Islam" was promoted. A Hamkorlik employee said that every Thursday a group of about ten Neophyte 
Christians gathered in private apartments, and that "a baptism ceremony was held in Lake Tashkent at least once with the direct participation of foreigners."

Along with the growing differentiation of non-profit organizations by forms and types of activities, support centers (resource centers), information services, training courses and seminars, newspapers and magazines began to appear, attempts were made to unite, the role of the nonprofit sector in the development of society and foreign experience in managing were actively discussed. non-profit organizations. [9]

The activities of such non-governmental organizations violated not only the legal, but also the moral aspect. Abusing the trust and affability of the Uzbek people, under the guise of charitable non-governmental organizations, a whole network of various Protestant religious organizations has been active in the country.

Thus, the Partnership in Academics and Development representative office has added to its list of foreign (primarily American) NGOs closed in Uzbekistan. Recall that for a short time in the republic, for various reasons, the representative offices of the following organizations were closed:

Soros Foundation / Open Society Institute;

Charity organization to support independent media Internews Network;

Council for International Research and Exchanges "IREX";

Human rights organization "Freedom House";

The Eurasia Foundation to support economic and democratic reforms in the CIS countries (Eurasia Foundation);

The Association of American Lawyers (ABA / CEELI);

American Council for Collaboration in Education and Language Learning ACCELS;

Organizations to improve the economic, environmental and social conditions of human development Counterpart International;

An organization that promotes cultural exchange in the field of education, cooperation in agriculture, medicine, business development and social security - Central Asian Free Exchange (CAFE);

Radio stations Liberty / Free Europe;

Global Involvement through Education (Global cooperation through education);

Organizations to improve the quality of life of both individuals and society as a whole, through the provision of direct humanitarian assistance - Crosslink Development International;

An organization that promotes the formation of local selfgovernment and the efficient management of public utilities - Urban Institute;

Office of the United Nations High Commissioner for Refugees (UNHCR);

Winrock International Institute for Agricultural Development (Winrock International);

"Human Rights Watch",
"Joint Development Associate International".

It is worth noting that about twelve foreign charitable organizations involved in humanitarian programs in Uzbekistan, ceased to exist in a short time this year due to the activities of the Uzbek authorities to close religious organizations. In some cases, the prohibition of activity was based only on a suspicion of involvement in religion. According to the employees of these organizations, the mission closure was most often the reason for the closure. According to experts, "several hundred" Protestants of Uzbekistan, who worked in foreign non-governmental organizations (NGOs), were forced to leave the country.

Before the American NGO Winrock International was deregistered, the Ministry of Justice of Uzbekistan sent a book published by this organization to the Committee for analysis, entitled "Islom dini hotin-kizlar" ("Islam and Women"). According to many experts, this book distorts the principles of true Islam and offends the feelings of Muslims."

Since 2004, the registration department of foreign NGOs has been responsible for the registration of public and religious organizations of the Ministry of Justice of Uzbekistan, to which these functions were transferred by the Ministry of Foreign Affairs. The last of the inspections of a religious organization by the Ministry of Justice was carried out in Tashkent, in the charity mission of Mother Teresa. The mission's activities were examined to ensure compliance with the laws of Uzbekistan and the conformity of the goals declared in the charter. It was a regular check.

The website of the Catholic Apostolic Administration in Uzbekistan, www.agnuz.info, reported that Mercy Missionaries arrived in the country in 1993. Their goal was to help street children, hospital patients and elderly people living alone. The Department of Justice re-registered a group of missionaries in March 2004.

Charity missionaries were aware of the planned inspection and were pleased that local authorities did not intend to close their organization's Uzbek branch. Unlike Protestants, Catholics have no problems with the authorities, and this may be explained by the fact that the Catholic Church is not engaged in missionary activity and does not preach among the Uzbeks.

In the early $90 \mathrm{~s}$ of the last century, many Muslim charitable organizations operated in Uzbekistan without registration, but after the adoption of the new Law on Religion in 1998, all of them were expelled from the country.

CAFE ultimately refused to protest the closure after a Tashkent court rejected the organization's complaint about earlier court orders in July. Legal actions of local authorities against CAFE offices in various cities throughout Uzbekistan began in April, most often these were accusations of the organization's proselytism.

In January 2006, authorities suspended the activities of two South Korean non-governmental organizations for three months: the Institute of Asian Culture and Development and the Korean Foundation for World Aid, accusing them of conducting Protestant "propaganda" and disseminating Protestant literature. 
In April, the Samarkand City Court found four foreign members of the local religious organization guilty of "trying to convert local residents to Protestantism" and fined them. This organization, under the guise of teaching English, foreign employees urged students of local universities to abandon Islam or Orthodoxy and accept Protestantism".

Along with the closure of foreign religious NGOs in early 2004, the Uzbek authorities began to close non-governmental organizations involved in political or social activities, and this process accelerated after the suppression of the Andijan uprising in May 2005. Closed organizations include Freedom House and Internews. In April 2006, the government closed the local office of the UN High Commissioner for Refugees.

Counterpart International is an American nongovernmental organization headquartered in Washington. The organization is funded by the US Department of State and the United States Agency for International Development (USAID). In Uzbekistan, the Counterpart International office, registered by the Ministry of Justice, has been operating for 11 years - since 1995 .

The main activities of this organization in Uzbekistan were humanitarian projects aimed at developing civil society, combating AIDS, and improving the health status of the population. Representation Counterpart International also sponsored programs to provide residents of disadvantaged regions of the republic with clean drinking water.

All this did not prevent the Ministry of Justice of Uzbekistan from submitting an idea on the liquidation of the representative office of this organization. Counterpart International is accused of systematically violating Uzbek laws and its own charter. According to the Ministry of Justice, representatives of the representative office created and headed local non-profit organizations, published printed materials without a license, and refused to provide financial documents to the authorities about their activities. In general, a list of standard charges was announced, followed by a trial and an imminent closure, as was already the case with the representations of other Western NGOs.

It is noteworthy that Uzbekistan is not the only CIS country expelling Counterpart International. In 2004, "due to a violation of the law," the representative office of this organization was deprived of accreditation with the Ministry of Foreign Affairs of Belarus, the last European country with a dictatorial form of government.

Along with a large number of non-profit and nongovernmental organizations that are truly civil society institutions and self-organization structures of citizens in various spheres of public life, there are organizations that are actively involved in the political process and foreign policy. Often, such activities are carried out by non-governmental organizations for grants from foreign agencies that pursue the goals of destabilizing public order, fragmenting society, changing state power, and the following areas are main in their activities:

Work with opposition parties, blocs and their youth structures;

Work with representatives of local governments, supposedly aimed at developing the independence of regions, and in practice, at weakening their manageability from the center;

Development of "alternative" state-owned media controlled by non-governmental organizations;

The creation of new and strengthening of existing public organizations, as well as the implementation through them of non-violent methods of struggle. [10]

We think that the main reasons for the closure of many foreign international organizations in Uzbekistan were as follows:

Intervention of the internal affairs of the Republic of Uzbekistan;

Disputation of the situation in the Republic of Uzbekistan;

Exit from statutory activities;

Missionary work and proselytism;

Propaganda of mass culture;

Lack of constructivism.

An attempt to commit a "color revolution" in the country;

Increase social discontent of the population against the state;

Illegal financial assistance to local NGOs for "special services", etc.

You can give a long list of how and where these policies were implemented. The overthrow of the Milosevic regime, the demise of E. Shevardnadze in November 2003 during the "Rose Revolution", V. Yushchenko came to power in Ukraine as a result of the "Orange Revolution" in December 2004, and the triumph of the Kyrgyz "Tulip Revolution" in March 2005 - links one chain. [11]

Thus, INGO began to wag strongly on domestic politics and contributed to the emergence of "color revolutions". Given the great threat to state security

We hold such a position that such a state attitude towards international non-governmental organizations was correct. Because, not timely awareness of the goals and intentions of such organizations would lead to unpredictable political and social consequences. This policy of the state served other organizations as a "clear signal" in order to comply with laws in the Republic.

\section{2. "The End of the Cold War" and the Beginning of a New Constructive Period of Cooperation}

Thanks to the far-sighted and friendly policy of President Sh. Mirziyoyev, the door was opened again for international non-governmental organizations. For example, on May 21, 2018, a delegation of the international non-governmental organization Amnesty International, headed by Marie Struters, Regional Director for Eastern Europe and Central Asia, arrived in Tashkent. During the visit, the delegation held meetings in the General Prosecutor's Office, the Supreme Court, the ministries of foreign affairs, internal affairs, justice, higher and secondary specialized education, the National Center for Human Rights of the Republic of Uzbekistan, the National Association of Non-Governmental and Non-Profit Organizations, the Independent Institute for Monitoring the Formation of Civil Society, with the 
Commissioner of the Oliy Majlis for Human Rights.

(For reference: Amnesty International is an international non-governmental organization founded in the UK in 1961, which aims to "undertake research and actions aimed at preventing and stopping violations of the rights to physical and psychological integrity, to freedom of conscience and expression, to freedom from discrimination in the context of their work to promote human rights").

According to the data, Amnesty International welcomes the willingness of the authorities of Uzbekistan to dialogue with the international human rights community. This visit was the first visit to Uzbekistan since 2004 for official representatives of Amnesty International. Then, in 2004, an international conference was held in Tashkent, organized by Amnesty International and the Uzbek human rights organization Mothers Against the Death Penalty and Torture. After that, the organization's activities in Uzbekistan ceased.

On October 29, 2017, representatives of the Freedom House human rights organization visited Uzbekistan and held several important official meetings with government organizations and non-governmental non-profit organizations (NGOs).

It is worth noting that the international human rights organization Freedom House opened an office in Uzbekistan in 2002, becoming an important resource center for human rights defenders of the country, but was forced to leave after the Andijan events on May 13, 2005 - then Tashkent expelled all international non-governmental organizations from the country. According to the latest Freedom House report "On Freedom in the World for 2018", Uzbekistan remains a "not free country."

In addition, another report published by Freedom Hours in 2014 on the level of freedom in individual countries where Uzbekistan belongs to the group of states with the lowest level of freedom $(36 \%$ of the population are politically unfree). The same group includes Zimbabwe, Sudan, Angola, Afghanistan, Somalia, Cambodia [12] In our opinion, this report is a "signal" for the state to continue carrying out large-scale reforms in all areas of the country's public life.

The number of countries considered "not free" is 53 (51 a year earlier). Among the post-Soviet states, this category includes: Russia, Azerbaijan, Belarus, Kazakhstan, Tajikistan, Turkmenistan, and Uzbekistan. According to the organization, the most disenfranchised in the world remain residents of states classified in the special category of "worst of the worst": Eritrea, North Korea, Uzbekistan, Somalia and Syria. [13] Thanks to this report, we will clearly set ourselves up in which areas we have big problems.

"The ongoing reforms under the new president, Shavkat Mirziyoyev, have led to the improvement of some issues. Uzbekistan is trying to enter the list of the most democratic countries in the world. Therefore, the Government of Uzbekistan listens to the recommendations of such international organizations and is actively working to implement these recommendations.

In this direction, the legislative and judicial bodies continue to act as instruments of the executive branch, while the media remain under the strict control of the state. Those responsible for endemic corruption or torture of detainees have little responsibility, despite some high-profile releases, the government continues to hold numerous prisoners for political or religious reasons".

\subsection{Priority Areas for Bilateral Cooperation}

In our opinion, international non-governmental organizations in their activities in Uzbekistan pay particular attention to the following issues:

Creation of democratic institutions;

Promoting the development of strong and independent media;

Development of civil society;

Support for civic education and humanitarian assistance;

Compliance with civil law;

Strengthening human rights;

Political modernization and tolerance;

Women's political rights;

Support for market reforms, charitable activities and environmental protection, etc.

However, some experts believe that even now, foreign states through international organizations impose on us economic, cultural and political dictates. [14]. However, we believe that this is wrong. Many non-governmental organizations work on democratic principles. In their activities, we observe openness, transparency, transparency, tolerance.

We think that action should be two-way. If somewhere our interests do not coincide, this does not mean that any cooperation is excluded. We have our own vision on some issues, international non-governmental organizations have their own vision. We will cooperate in a space where our interests coincide and, through joint efforts, expand it, discuss disputed issues, and make decisions on them so that we have more mutual understanding and friendly relations. In recent years, Uzbekistan has become a tolerant country for all international non-governmental organizations.

\section{Discussion}

In this article we focused on the question "on what basis" did the Uzbek government conflict with INGOs. Why and why the Ministry of Justice of Uzbekistan canceled the accreditation of INGOs in the country. What claims did INGOs bring to the government of Uzbekistan?

In our opinion, the claims of the Government of Uzbekistan were correct and adequate. Since they were engaged in affairs that are not included in their statutory tasks. In addition, they tried to destabilize the situation inside the country.

For this reason, the termination of the activities of INGOs in Uzbekistan was the right decision. Thus, the government of Uzbekistan did not allow "third parties" to make "color revolutions" in Uzbekistan. This has led to the stabilization of the situation in the country and the strengthening of state supervision of international and local NGOs. 
When President Sh. Mirziyoyev came to power, there was a real chance for a "restart" of relations between Uzbekistan and INGOs. Since they began to contribute to the integration of Uzbekistan into the global civil society and the strengthening of democratic principles.

\section{Conclusions}

And so, at the present stage of development of Uzbekistan, one of the priorities of the political development of Uzbekistan is the development of civil society institutions. The state, implementing a policy of social partnership, encourages the activities of international non-governmental organizations and the development of local nongovernmental organizations. NGOs act as a new mechanism, as opposed to state power, in the democratization of society, in the protection of human rights, opening the door for widespread participation of the masses and promoting pluralism in society.

Most leaders of Chinese NGOs see their mission as fulfilling their civic responsibility through cooperation with the government [15]. This state of affairs contributed to the emergence of the so-called non-governmental organizations created by the government or with the guarantee of a state institution.

It is difficult to overestimate the role and importance of these organizations in strengthening democratic values in the minds of people, increasing their political and civic activism, expanding the scale and deepening of the democratic transformations taking place in the country.

\section{Acknowledgements}

I want to thank the editorial boards of the journal for providing methodological assistance. Thanks to them, I learned the flaws and errors in writing a scientific article.

\section{References}

[1] Report of the Committee on Non-Governmental Organizations - on the work of its resumed 2014 session (New York, May 18-27, 2014) / 2014 substantive session - ECOSOC - Geneva, July 6-30, 2014 - E / 2009/32 (Part II).

[2] CamiUeri J., Falk J. The End of Sovereignty? The Politics of a Shrinking and Fragmenting World, Aldershot, UK, 1992.
[3] Spiro P. New global communities: nongovernmental organizations in international decision making institutions // Washington Quarterly, 18 (1), 1995.

[4] Strengthening the role of non-governmental organizations: partners in the process of sustainable development // Agenda 21 / Section III / Chapter 27 [Electronic resource] URL: http: //www.un.org/russian/conferen/wssd/agenda21/part3/ch27.htm (accessed 04.21.17).

[5] Buneeva R. I. Problems of development of non-profit organizations. URL:

www.stu.lipetsk.ru/files/materials/612/buneeva.doc (accessed September 3, 2018).

[6] Natalia Miheeva. The transformation of international nongovernment organizations fields of activity from the second half of the $\mathrm{xx}$ century. // Universum: Social Sciences: Electron. scientific journal 2017. No. 9 (39) p. 22. URL: http://7universum.com/en/social/archive/item/5138 (accessed date: $02 / 08 / 2020$ ).

[7] Yuri V. Mishalchenko. International non-governmental organizations: the development of legislation on the example of the CIS countries. 2018. p-3.

[8] Yuri V. Mishalchenko. International non-governmental organizations: the development of legislation on the example of the CIS countries. 2018. p-4.

[9] Panasenko S. Development of the non-profit sector in Russia URL:

http://observer.materik.ru/observer/N7_2006/7_06.HTM (accessed: 03.09.2018).

[10] Minasyan G., Voskanyan A., Minasyan G., Voskanyan A. Foreign NGOs - mechanisms of influence on domestic policy // Observer, 2013.№ 3. C- 15.

[11] Minasyan G., Voskanyan A., Minasyan G., Voskanyan A. Foreign NGOs - mechanisms of influence on domestic policy // Observer, 2013.№ 3.. C- 16.

[12] Map of Freedom 20016 [Electronic resource] URL: http: //www.freedomhouse.org/uploads/fiw09/MOF09.pdf (accessed 05.21.2017).

[13] FREEDOM IN THE WORLD OF 2016. 01/28/2016. ttps: //gtmarket.ru/news/2016/01/28/7290.

[14] Naumov A. O. International non-governmental organizations in the modern world political system. - M.: KRASAND, 2009. p. 31 .

[15] Semenov A. A. Features of the legislation of the PRC in public organizations and NGOs // Bulletin of the Irkutsk State University. 2017. V. 20. P. 60. 